\title{
The impact of VAT instead of the business tax on the financial performance of Listed Companies in Heilongjiang
}

\author{
Wen Li ${ }^{1, a}$, Yingying Tao ${ }^{2, b}$ \\ ${ }^{1}$ No. 705, Rong Jiang Road, Daoli District, Harbin, Heilongjiang, China \\ ${ }^{2}$ Songbei, Harbin, Heilongjiang, China \\ ahrbsydxlw@163.com, b942420939@qq.com,
}

Keywords: VAT instead of the business tax; tax rate; financial performance

\begin{abstract}
This paper takes the listed companies in Heilongjiang Province from 2013 to 2016 as the research samples from the perspective of financial practitioners. Through empirical analysis of VAT instead of the business tax policy on the financial performance of Listed Companies in Heilongjiang Province changes, check the implementation effect of the policy. The impact of the policy on the company's financial performance is not significant. After the reform, the average level of real tax burden of turnover tax has not declined significantly.
\end{abstract}

\section{Introduction}

On May 1, 2016, the VAT instead of business tax in the financial industry, construction industry, real estate industry and life service industry. This is an important structural tax reduction policy, not only conducive to promoting the development of the tertiary industry, but also conducive to the adjustment of the industrial structure and the transformation of the mode of economic development. With the implementation of reform in various industries, the results and problems are gradually revealed. This paper selects listed companies in Heilongjiang Province as the research sample to analyze the related issues of financial performance of listed companies under this policy.

\section{Research hypothesis}

According to the regulations, the input tax of fixed assets newly purchased by enterprises which can be used for more than 12 months in connection with production and operation activities is allowed to be deducted. This will inevitably have an impact on the financial performance of some listed companies, but because Heilongjiang Province is not within the scope of the trial, the following assumptions are proposed:

Hypothesis 1: Business tax reform VAT Policy has no significant impact on the financial performance of Listed Companies in Heilongjiang.

Hypothesis 2: Business tax reform VAT Policy has a significant impact on the turnover tax burden of Listed Companies in Heilongjiang.

Hypothesis 3: There is a negative correlation between turnover tax burden and financial performance of Listed Companies in Heilongjiang.

Hypothesis 4: There is a positive correlation between the proportion of production cost to total operating cost and financial performance.

Hypothesis 5: There is a negative correlation between fixed assets turnover and financial performance.

\section{Data sources and sample selection}

\subsection{Sources of data}

The data needed in this paper come from Cathay Tai'an database (http://www.gtarsc.eom/p/sq/) Tide information website (http://www.cninfo.com.cn/) and the annual reports of listed companies. 
Using Excel office software and SPSS19.0 statistical software to process all data.

\subsection{Sample selection}

This article is classified according to the industry classification standard of the SFC in 2013. Analysis of the business tax reform VAT Policy influence of Heilongjiang listed company on corporate financial performance. In order to eliminate the influence of heterogeneous sample data on the conclusions of the study, the data were screened as follows:

(1) Excluding a series of listed companies that are subjected to special treatment (ST).

(2) Excluding a series of listed companies with incomplete financial data.

By screening the data of the annual and semi-annual reports from 2013 to 2016, 29 samples of Listed Companies in Heilongjiang Province in Shanghai and Shenzhen stock markets were obtained.

\section{Research design}

\subsection{Variable selection and interpretation}

Through the theoretical analysis of Chapter 4 and considering the availability of data, the research variables and specific meanings involved in this paper are shown in Table 1.

Table 1 Meaning table of research variables

\begin{tabular}{|c|c|c|c|}
\hline Symbol & Meaning & Calculation formula & $\begin{array}{l}\text { Variable } \\
\text { type }\end{array}$ \\
\hline $\mathrm{ROE}_{\text {it }}$ & Net asset yield & Current net profit / average net assets & $\begin{array}{l}\text { dependent } \\
\text { variable }\end{array}$ \\
\hline BTV & $\begin{array}{l}\text { VAT instead of the business } \\
\qquad \operatorname{tax}\end{array}$ & $\begin{array}{c}0 \text { indicates that before the } \\
\text { implementation of business tax to } \\
\text { VAT, } 1 \text { indicates that after the } \\
\text { implement. }\end{array}$ & $\begin{array}{l}\text { independent } \\
\text { variable }\end{array}$ \\
\hline $\mathrm{CTR}_{\text {it }}$ & Actual tax rate of transfer tax & $\begin{array}{l}\text { (VAT and business tax and additional) } \\
\text { / total revenue }\end{array}$ & $\begin{array}{l}\text { independent } \\
\text { variable }\end{array}$ \\
\hline $\mathrm{MIR}_{\text {it }}$ & $\begin{array}{l}\text { The deductible production } \\
\text { cost accounts for the } \\
\text { proportion of the total cost of } \\
\text { business }\end{array}$ & $\begin{array}{l}\text { (total operating cost - payable staff } \\
\text { salaries) / total operating cost X 100\% }\end{array}$ & $\begin{array}{l}\text { independent } \\
\text { variable }\end{array}$ \\
\hline $\mathrm{FAT}_{\text {it }}$ & Fixed assets turnover & $\begin{array}{l}\text { Current operating income/Average } \\
\text { balance of fixed assets }\end{array}$ & $\begin{array}{l}\text { independent } \\
\text { variable }\end{array}$ \\
\hline $\mathrm{LEV}_{\text {it }}$ & $\begin{array}{l}\text { Company's asset liability } \\
\text { ratio }\end{array}$ & Total liabilities / total assets & $\begin{array}{c}\text { control } \\
\text { variable }\end{array}$ \\
\hline SIZE $_{\text {it }}$ & Enterprise scale & $\begin{array}{l}\text { Natural logarithm of total capital } \\
\text { production }\end{array}$ & $\begin{array}{l}\text { control } \\
\text { variable }\end{array}$ \\
\hline $\mathrm{GRP}_{\text {it }}$ & Gross interest rate & Gross profit / operating income x $100 \%$ & $\begin{array}{c}\text { control } \\
\text { variable }\end{array}$ \\
\hline $\mathrm{CR}_{\text {it }}$ & ownership structure & $\begin{array}{l}\text { The number of the top five } \\
\text { shareholders / the total share capital of } \\
\text { the company }\end{array}$ & $\begin{array}{c}\text { control } \\
\text { variable }\end{array}$ \\
\hline
\end{tabular}

\subsection{The construction of the model}

In order to test the hypothesis in this paper, the following models are designed according to the relevant principles.

$$
\mathrm{ROE}_{\mathrm{it}}=\mathrm{a}_{0}+\beta_{1} \mathrm{BTV}+\beta_{2} \mathrm{CTR}_{\mathrm{it}}+\beta_{3} \mathrm{MIR}_{\mathrm{it}}+\beta_{4} \mathrm{FAT}_{\mathrm{it}}+\beta_{5} \mathrm{LEV}_{\mathrm{it}}+\beta_{6} \mathrm{SIZE}_{\mathrm{it}}+\beta_{7} \mathrm{CR}_{\mathrm{it}}+\beta_{8} \mathrm{GPR}_{\mathrm{it}}+\mu_{\mathrm{it}}
$$

Among them, $\mathrm{i}$ is the company, $\mathrm{t}$ represents the year, and Muon is residual. 


\section{Empirical analysis}

\subsection{Descriptive statistical analysis}

This paper uses SPSS19.0 to make descriptive statistical analysis of the main variables. The results of the descriptive statistical analysis of the 2013-2016 year general samples are shown in Table 2, table 3, table 4, and table 5.

Table 22013 descriptive statistics for samples

\begin{tabular}{llllll}
\hline & $\mathrm{N}$ & $\begin{array}{l}\text { Minimum } \\
\text { value }\end{array}$ & $\begin{array}{l}\text { maximum } \\
\text { value }\end{array}$ & mean value & $\begin{array}{l}\text { standard } \\
\text { deviation }\end{array}$ \\
\hline Net asset yield & 58 & -0.282800 & 0.315100 & 0.029048 & 0.079926 \\
$\begin{array}{l}\text { Actual tax rate of transfer tax } \\
\text { Main business cost account for }\end{array}$ & 58 & -0.003900 & 0.763200 & 0.087588 & 0.121258 \\
total operating cost ratio & 58 & 0.862200 & 1.000000 & 0.979038 & 0.026328 \\
Fixed assets turnover & 58 & 0.108700 & 123.808500 & 5.826307 & 17.321821 \\
Asset liability ratio & 58 & 0.137400 & 0.886900 & 0.485653 & 0.213068 \\
Enterprise scale & 58 & 8.788300 & 10.929500 & 9.564633 & 0.463329 \\
Gross interest rate & 58 & -0.001500 & 0.771400 & 0.273712 & 0.200973 \\
ownership structure & 58 & 18.900000 & 75.960000 & 49.491897 & 15.364251 \\
Effective N (list state) & 58 & & & & \\
\hline
\end{tabular}

Table 32014 descriptive statistics for samples

\begin{tabular}{llllll}
\hline & $\mathrm{N}$ & $\begin{array}{l}\text { Minimum } \\
\text { value }\end{array}$ & $\begin{array}{l}\text { maximum } \\
\text { value }\end{array}$ & mean value & $\begin{array}{l}\text { standard } \\
\text { deviation }\end{array}$ \\
\hline Net asset yield & 58 & -1.925900 & 0.209500 & -0.008540 & 0.291665 \\
$\begin{array}{l}\text { Actual tax rate of transfer tax } \\
\text { Main business cost account for }\end{array}$ & 58 & -0.010100 & 0.186700 & 0.059184 & 0.047684 \\
total operating cost ratio & & 0.861400 & 1.000000 & 0.975041 & 0.032868 \\
$\begin{array}{l}\text { Fixed assets turnover } \\
\text { Asset liability ratio }\end{array}$ & 58 & 0.009600 & 145.643000 & 5.917241 & 20.376507 \\
$\begin{array}{l}\text { Enterprise scale } \\
\text { Gross interest rate }\end{array}$ & 58 & 0.137800 & 0.996100 & 0.476731 & 0.218349 \\
ownership structure & 58 & 8.802800 & 11.035200 & 9.593890 & 0.480075 \\
Effective N (list state) & 58 & -0.160000 & 0.683100 & 0.290150 & 0.202023 \\
\hline
\end{tabular}

Table 4 2015descriptive statistics for samples

\begin{tabular}{llllll}
\hline & $\mathrm{N}$ & $\begin{array}{l}\text { Minimum } \\
\text { value }\end{array}$ & $\begin{array}{l}\text { maximum } \\
\text { value }\end{array}$ & mean value & $\begin{array}{l}\text { standard } \\
\text { deviation }\end{array}$ \\
\hline $\begin{array}{l}\text { Net asset yield } \\
\text { Actual tax rate of transfer tax }\end{array}$ & 58 & -18.841300 & 2.007400 & -0.212379 & 2.514915 \\
$\begin{array}{l}\text { Main business cost account for } \\
\text { total operating cost ratio }\end{array}$ & 58 & -0.052000 & 0.176900 & 0.064971 & 0.055389 \\
Fixed assets turnover & 58 & 0.136000 & 144.376600 & 6.600555 & 20.882662 \\
Asset liability ratio & 58 & 0.028200 & 1.360100 & 0.480636 & 0.279140 \\
Enterprise scale & 58 & 8.473700 & 11.183000 & 9.616190 & 0.539148 \\
Gross interest rate & 58 & -0.165700 & 0.683800 & 0.277105 & 0.208345 \\
ownership structure & 58 & 18.280000 & 80.990000 & 48.415172 & 15.165663 \\
Effective N (list state) & 58 & & & & \\
\hline
\end{tabular}


Table5 2016 descriptive statistics for samples

\begin{tabular}{cccccc}
\hline & $\mathrm{N}$ & $\begin{array}{c}\text { Minimum } \\
\text { value }\end{array}$ & $\begin{array}{c}\text { maximum } \\
\text { value }\end{array}$ & mean value & $\begin{array}{c}\text { standard } \\
\text { deviation }\end{array}$ \\
\hline Net asset yield & 58 & -0.234400 & 0.306500 & 0.054397 & 0.073318 \\
Actual tax rate of transfer tax & 58 & -0.008000 & 0.229000 & 0.061766 & 0.052701 \\
$\begin{array}{c}\text { Main business cost account for } \\
\text { total operating cost ratio }\end{array}$ & 58 & 0.749300 & 1.000000 & 0.970959 & 0.044592 \\
Fixed assets turnover & 58 & 0.128400 & 163.659400 & 7.922671 & 23.994608 \\
Asset liability ratio & 58 & 0.146900 & 1.442500 & 0.475884 & 0.240473 \\
$\quad$ Enterprise scale & 58 & 8.566200 & 11.203900 & 9.727214 & 0.552552 \\
Gross interest rate & 58 & -0.149300 & 0.792300 & 0.275567 & 0.198620 \\
ownership structure & 58 & 20.050000 & 83.540000 & 51.337241 & 14.550687 \\
Effective N (list state) & 58 & & & & \\
\hline
\end{tabular}

From the descriptive statistics in the above table, we can find the overall statistics of 29 samples from 2013 to 2016.

From the perspective of return on net assets, the average return on net assets in 2013-2016 are $0.079179,0.029048,-0.008540,-0.212379$ and 0.054397 , respectively.From 2013 to 2015, the trend was decreasing year by year, and it increased rapidly in 2016. With the implementation of business tax reform VAT Policy, the financial performance of Listed Companies in Heilongjiang has increased slightly.

From the perspective of fixed asset turnover rate, the average fixed asset turnover rate from 2013 to 2016 is $7.844328,5.826307,5.917241,6.600555$ and 7.922671 respectively.On the whole, it has been increasing year by year since 2013.The statistical results show that the new fixed assets investment of Listed Companies in Heilongjiang Province did not increase significantly before and after the reform.

\subsection{Complete sample regression analysis}

In order to study the effect of VAT on the financial performance of the pilot listed companies of the traffic and transportation industry, this paper returns all the related financial data of the 29 sample enterprises in 2013-2016 and a half year and the year, and the results are shown in table 6 as follows.

Table 6 the return of VAT instead of business tax on the financial performance of Heilongjiang listed companies

\begin{tabular}{cccccc}
\hline & \multicolumn{2}{c}{$\begin{array}{c}\text { Non standardized } \\
\text { coefficient }\end{array}$} & $\begin{array}{c}\text { Standard } \\
\text { coefficient }\end{array}$ \\
& Standard & & & \\
Model & B & error & Beta & t & Sig. \\
\hline (constant) & -1.586848 & 3.065966 & & -0.517569 & 0.605213 \\
VAT on business tax & 0.047303 & 0.180111 & 0.016535 & 0.262634 & 0.793048 \\
Actual tax rate of transfer & -0.579669 & 1.073092 & -0.036435 & -0.540186 & 0.589546 \\
tax & & & & & \\
Main business cost account & -0.352849 & 2.291909 & -0.010421 & -0.153954 & 0.877769 \\
for total operating cost ratio & & & & \\
Fixed assets turnover & 0.000316 & 0.003880 & 0.005372 & 0.153954 & 0.935241 \\
Asset liability ratio & 0.000990 & 0.017528 & 0.003601 & 0.056485 & 0.955000 \\
$\quad$ Enterprise scale & 0.185183 & 0.157080 & 0.078567 & 1.178910 & 0.239546 \\
Gross interest rate & -0.451303 & 0.408880 & -0.076012 & -1.103755 & 0.270752 \\
ownership structure & 0.005812 & 0.005061 & 0.073699 & 1.148312 & 0.251929 \\
\hline
\end{tabular}




\section{Conclusion}

In this paper, the object of this study is listed companies in Heilongjiang Province in 2013-2016 years. By proposing assumptions and building models. This paper analyzes the specific impact on financial performance of Listed Companies in Heilongjiang Province, including the change of actual tax rate, the deduction effect of production cost and the turnover rate of fixed assets. The conclusions are as follows:

(1)Business tax is converted to VAT has no significant impact on the financial performance of Listed Companies in Heilongjiang. The standardized regression coefficient of the company's net assets yield is 0.016535 . The $\mathrm{P}$ value is 0.793048 . It does not pass the significant test.

(2) There is a negative correlation between the actual tax rate of the circulation tax and the financial performance of the listed companies in Heilongjiang, but the actual tax rate does not have a significant impact on the corporate financial performance after the policy According to the results of the regression, the influence coefficient of the two is -0.010421 . The $\mathrm{P}$ value is 0.589546 , and it has not passed the significant test. Because the implementation of the policy is not long.

(3) There is a positive correlation between the fixed assets turnover rate and the corporate financial performance of the listed companies in Heilongjiang. But the effect of the fixed assets tax deduction on the corporate financial performance is not significant. According to the regression results, the influence coefficient of the fixed assets turnover rate on the financial performance of the enterprises is 0.005372 , it shows a positive correlation. But the $\mathrm{P}$ value is 0.935241 . Significance test did not pass. It shows that the financial performance is not significantly affected by the tax deduction effect of newly added fixed assets investment.

\section{Acknowledgements}

This paper is the stage research result of Heilongjiang Province Philosophy and Social Sciences Project "The Impact of Business Reform and Increase on Financial Performance of Heilongjiang Listed Companies" (No. 17GLD172) in 2017.

This paper is supported by the innovative research project of Harbin Business University in 2018, the impact of environmental protection tax on enterprise financial performance under the concept of ecological civilization (project number: YJSCX2018-507HSD).

\section{References}

[1] Ruyan Wang, Wu Limei, Wu Zhanxia and Wu Wei. Reflections on the VAT instead of the business tax in Transportation Industry [J].Tax Research, 2014 (04): 57-62

[2] Qing Chen. VAT instead of the business tax: achievements, problems and Countermeasures [J]. tax research, 2015 (01): 95 98

[3] Yan Lian. The Impact of VAT instead of the business tax on Transportation Industry and Its Upstream and Downstream Enterprises [J].Business Accounting, 2014 (04): 43-44

[4] Dan Zhang, Qiuxu Yang. The effect of the tax burden of transportation enterprises by the policy of the VAT instead of the business tax - Analysis of the pilot policy based on the reform of Shanghai [J]. Finance and Accounting Monthly, 2013 (02): 83 87

[5] Hongjuan Li. Study on the impact of "VAT instead of the business tax " on tax planning for transportation enterprises [J] Friends of Accountants, 2014 (17): 100-102

[6] Wei Li, Weiping Li. Research on the Influence of VAT instead of the business tax on Tax Burden and Finance of Transportation Listed Companies [J].Shanghai Economic Research, 2016 (01): 61-69

Wen Li, born in August 1968, is a female, Han nationality, master of Weishan in Shandong, master of Harbin University of Commerce, tutor of master's degree.

Yingying Tao, born in February 1994, female, Han nationality, Harbin, Heilongjiang, master of Harbin University of Commerce. 